\title{
PENGARUH NHT BERBANTU MEDIA ULAR TANGGA UNTUK MENINGKATKAN MINAT BELAJAR
}

\author{
Nur Maria Ulfa ${ }^{1}$, Aries Tika Damayani ${ }^{2}$, Rofian $^{3}$ \\ Fakultas Ilmu Pendidikan, Universitas PGRI Semarang \\ email: nurmariaulfa05@gmail.com
}

\begin{abstract}
This researched to determine and analyze the effect of the snake ladder media Numbered Head Together (NHT) learning model to increase the learning interest of Grade II students at SDN Menur Mranggen Demak. This type of research was quantitative in the form of Pre-Experimental Design with the type of One-Group Pretest-Posttest Design. Data obtained through observation, documentation, tests, questionnaires, and interviews. The background of this study is due to the lack of use of models and instructional media which results in less interesting learning and was an impact on students' interest in learning and student learning outcomes on Indonesian subjects. The results of the analysis of student learning interest questionnaire data showed that the average pretest was 57.88. After being treated with this learning model, the posttest mean increased to 71.70. While the analysis of student learning outcomes data obtained an average pretest value of 62.59 and the average posttest value of 79.62. The conclusion was that there is a significant influence on the snake ladder's Numbered Head Together (NHT) learning model to increase the interest in learning in class II SDN Menur Mranggen Demak.
\end{abstract}

Keywords: Numbered Head Together, snake and leadder Adit Sopo Jarwo, interest in learning

\begin{abstract}
Abstrak
Penelitian ini bertujuan untuk mengetahui dan menganalisis pengaruh model pembelajaran Numbered Head Together (NHT) berbantu media ular tangga untuk meningkatkan minat belajar siswa kelas II SDN Menur Mranggen Demak. Jenis penelitian ini adalah kuantitatif dalam bentuk Pre-Experimental Design dengan jenis One-Group Pretest-Posttest Design. Data diperoleh melalui observasi, dokumentasi, tes, angket, dan wawancara. Latar belakang penelitian ini dikarenakan kurangnya penggunaan model dan media pembelajaran yang mengakibatkan pembelajaran kurang menarik dan berdampak pada minat belajar dan hasil belajar siswa rendah pada mata pelajaran Bahasa Indonesia. Hasil analisis data angket minat belajar siswa menunjukan bahwa rata-rata pretest adalah 57,88. Setelah diberi perlakuan dengan model pembelajaran ini, rata-rata posttest meningkat menjadi 71,70. Sedangkan analisis data hasil belajar siswa diperoleh nilai rata-rata pretest 62,59 dan rata-rata nilai posttest 79,62. Kesimpulannya bahwa ada pengaruh signifikan model pembelajaran Numbered Head Together (NHT) berbantu media ular tangga untuk meningkatkan minat belajar siswa kelas II SDN Menur Mranggen Demak.
\end{abstract}

Kata kunci : Numbered Head Together, ular tangga Adit Sopo Jarwo, minat belajar 


\section{PENDAHULUAN}

Berhasil tidaknya proses

pembelajaran untuk mencapai tujuan banyak dipengaruhi oleh proses belajar yang dialami oleh siswa (Sutikno, 2013:3). Begitu juga peningkatan keberhasilan proses pembelajaran dituntut keberhasilan guru dalam memilih dan menentukan strategi belajar yang mampu membawa siswa pada situasi yang aktif sehingga siswa dapat mengembangkan kemampuan belajarnya secara maksimal. Kegiatan belajar mengajar yang dilakukan oleh guru tidak lepas dari beberapa permasalahan pengelolaan kelas. Setiap guru memasuki ruang kelas dituntut untuk mampu mengelola kelas sebaik mungkin dari awal hingga akhir kegiatan pembelajaran. Jadi, masalah pengaturan kelas ini tidak akanpernah sepi dari kegiatan guru.

Berdasarkan hasil observasi penelitian mengenai kegiatan belajar mengajar pada kela II SD Negeri Menur Mranggen Demak, siswa kurang berminat dalam mengikuti pembelajaran. Saat dalam kelas siswa lebih suka bermain sendiri, bahkan ada yang tidak tertarik pada penjelasan guru, ketika guru memberikan pertanyaan, siswa tidak menanggapinya, bahkan saat siswa ditunjukpun tidak mau menjawab.

Berdasarkan masalah yang ada pada kegiatan pembelajaran Bahasa Indonesia di SD Negeri Menur Mranggen Demak ketika guru dalam proses belajar mengajarnya kurang bervariasi. Hal ini mengakibatkan siswa cepat merasa bosan karena guru selalu menggunakan metode ceramah. Sesuai dengan Djamarah (2010:124) yang mengemukakan bahwa hal tersebut bagian dari sesuatu yang tidak menyenangkan. Demikian juga dalam proses belajar mengajar tidak menggunakan variasi, maka akan membosankan bagi siswa. Hal itulah yang membuat siswa kurang berminat dalam belajar Bahasa Indonesia sehingga berdampak pada rendahnya hasil belajar siswa, karena pada dasarnya minat terhadap sesuatu merupakan hasil belajar dan menyokong belajar selanjutnya (Slameto, 2010:180). Rendahnya hasil belajar kelas II SD Negeri Menur Mranggen Demak yang masih dibawah KKM yaitu 70. Hal ini 
dibuktikan dengan hasil dari Ulangan Tengah Semester.

Salah satu model pembelajaran yang dapat diterapkan pada materi memahami teks dengan membaca lancar dan membaca puisi anak di SD Negeri Menur Mranggen Demak yaitu Numbered Head Together (NHT), model ini dapat meningkatkan minat belajar dan hasil belajar siswa. Selain pemilihan model pembelajaran, penggunaan media pembelajaran juga dapat membantu meningkatkan minat dan hasil belajar Bahasa Indonesia, karena kegiatan belajar anak didik dengan bantuan media akan menghasilkan proses dan hasil belajar yang lebih baik dari pada tanpa bantuan media (Djamarah, 2010:122). Media yang digunakan peneliti adalah ular tangg Adit Sopo Jarwo. berdasarkan uraian latar belakang di atas memberikan arahan dan dorongan bagi penulis untuk mengadakan penelitian dengan judul pengaruh model pembelajaran Numbered Head Together (NHT) berbantu media ular tangga Adit Sopo Jarwo untuk meningkatkan minat belajar siswa kelas II SD N Menur Mranggen Demak.

\section{METODE PENELITIAN}

Metode yang digunakan dalam penelitian adalah metode eksperimen. Metode eksperimen merupakan metode penelitian yang digunakan untuk mencari pengaruh treatmen (perlakuan) tertentu (Sugiyono, 2016:72). Metode penelitian eksperimen adalah metode penelitian yang digunakan untuk mencari pengaruh perlakuan tertentu terhadap yang lain dalam kondisi yang terkendalikan.

Desain penelitian yang digunakan penelitian ini adalah PreExperimental Design dengan jenis One-Group Pretest-Posttest Design. Teknik sampling yang digunakan dalam penelitian ini adalah nonprobability sampling dengan jenis sampling jenuh. Teknik pengumpulan data yang digunakan pada penelitian ini menggunakan metode tes dan non tes yaitu 1) angket; 2) observasi; 3) wawancara.

Teknik analisis data yang digunakan dalam penelitian ini menggunakan uji prasyarat yaitu uji normalitas awal dan akhir untuk mengetahui data berdistribusi normal atau tidak, sedangkan uji hipotesis 
Jurnal Sinektik

Volume 2 Nomor 2, Edisi Desember 2019

Prodi PGSD Universitas Slamet Riyadi

ISSN 2620-6560 (print) ISSN 2620-746X (online)

menggunakan uji t satu sampel untuk mengetahui apakah model pembelajaran Numbered Head Together (NHT) berbantu media ular tangga berpengaruh terhadap minat dan hasil belajar Bahasa Indonesia materi memahami teks dengan membaca lancar dan membaca puisi anak.

\section{HASIL DAN PEMBAHASAN}

Data yang digunakan dalam penelitian ini diperoleh dari hasil pretest dan posttest siswa.

\section{Minat Belajar}

Data yang digunakan dalam penelitian ini diperoleh dari hasil pretest dan posttest siswa. Nilai minat belajar siswa tiap indikator yang diperoleh dari angket pretest atau sebelum diberi perlakuan menunjukan persentase pada indikator minat terhadap rasa suka mencapai $63 \%$ sebanyak 12 siswa terhadap antusias mencapai $58 \%$ sebanyak 11 siswa, minat terhadap perhatian mencapai $66 \%$ sebanyak 13 siswa, minat terhadap keinginan atau kemauan mencapai $70 \%$ sebanyak 16 siswa, dan minat terhadap rasa ingin tahu mencapai
79\% sebanyak 19 siswa. Pada hasil persentase ketercapaian klasikal mencapai $67 \%$. Sedangkan pada posttest atau setelah diberi perlakuan dengan model pembelajaran Numbered Heads Together (NHT) berbantu media ular tangga Adit Sopo Jarwo menunjukan bahwa persentase pada indikator minat terhadap rasa suka mencapai $80 \%$ sebanyak 20 siswaterhadap antusias mencapai $85 \%$ sebanyak 21 siswa, minat terhadap perhatian mencapai $77 \%$ sebanyak 17 siswa, minat terhadap keinginan atau kemauan mencapai 90\% sebayak 24 siswa, dan minat terhadap rasa ingin tahu mencapai $78 \%$ sebanyak 18 siswa. Pada hasil persentase ketercapaian klasikal mencapai $82 \%$.

Ada penurunan persentase antara pretest dan posttest pada indikator rasa ingin tahu yang awalnya $79 \%$ turun menjadi $78 \%$. Berdasarkan persentase kenaikan pretest dan posttest minat belajar yang diperoleh dapat disimpulkan bahwa ada pengaruh pada minat belajar siswa kelas II di SD Negeri Menur Mranggen Demak. 


\section{Hasil Belajar}

Dapat diketahui bahwa frekuensi hasil belajar pretest yang memperoleh nilai $35-41$ sebanyak 1 siswa atau 3,7\%, nilai 42 - 48 sebanyak 1 siswa atau $3,7 \%$, nilai 49 - 55 sebanyak 4 siswa atau $14,8 \%$, nilai 56 - 62 sebanyak 6 siswa atau 22,2\%, nilai 63 - 69 sebanyak 6 siswa atau $22,2 \%$, dan nilai 70 - 76 sebanyak 9 siswa atau 33,3\%. Rata-rata nilai hasil belajar pretest atau sebelum diberi perlakuan adalah 62,6 bila dilihat dari kriteria ketuntasan minimum (KKM) adalah 70, masuk dalam kategori tidak tuntas. Hasil nilai pretest tersebut menunjukan bahwa hasil belajar siswa masih rendah, sehingga dibutuhkan treatment untuk meningkatkan hasil belajar siswa

\section{a. Uji Persyaratan Analisis Data}

1. Analisis Data Awal (Uji Normalitas)

Tabel 1. Normalitas Awal Angket Minat Belajar dan Tes Hasil Belajar

\begin{tabular}{lccccc}
\hline \multirow{2}{*}{ Variabel } & \multicolumn{4}{c}{ Data } & Kesimpulan \\
\cline { 2 - 5 } & $\mathrm{N}$ & $\alpha$ & $\mathrm{L}_{\mathrm{o}}$ & $\mathrm{L}_{\text {tabel }}$ & \\
\hline $\begin{array}{l}\text { Minat } \\
\text { belajar }\end{array}$ & 27 & 0,05 & 0,063 & 0,168 & $\begin{array}{l}\text { Berdistribusi } \\
\text { normal }\end{array}$ \\
\hline $\begin{array}{l}\text { Hasil } \\
\text { belajar }\end{array}$ & 27 & 0,05 & 0,101 & 0,168 & $\begin{array}{l}\text { Berdistribusi } \\
\text { normal }\end{array}$ \\
\hline \multicolumn{4}{c}{ Berdasarkan tabel 1 di } \\
& atas & \multicolumn{3}{c}{ diperoleh } & taraf
\end{tabular}

signifikan $5 \%$ didapat $\mathrm{L}_{\text {tabel }}=0,168$ minat belajar dengan diperoleh $\mathrm{L}_{\mathrm{o}}<\mathrm{L}_{\text {tabel }}$ atau $\quad(0,063<0,168) \quad$ dan $\mathrm{L}_{0}<\mathrm{L}_{\text {tabel }}$ dan hasil belajar $(0,101<0,168)$ maka $H_{0}$ diterima, sehingga sampel berasal dari populasi berdistribusi normal.

\section{Analisis Data Akhir (Uji} Normalitas)

Tabel 2. Normalitas Akhir Minat Belajar dan Tes Hasil Belajar

\begin{tabular}{lccccl} 
& \multicolumn{5}{c}{ dan Tes Hasil Belajar } \\
\cline { 2 - 5 } Variabel & \multicolumn{4}{c}{ Data } & Kesimpulan \\
& $\mathrm{N}$ & $\alpha$ & $\mathrm{L}_{\mathrm{o}}$ & $\mathrm{L}_{\text {tabel }}$ & \\
\hline $\begin{array}{l}\text { Minat } \\
\text { belajar }\end{array}$ & 27 & 0,05 & 0,105 & 0,168 & $\begin{array}{l}\text { Berdistribusi } \\
\text { normal }\end{array}$ \\
\hline $\begin{array}{l}\text { Hasil } \\
\text { belajar }\end{array}$ & 27 & 0,05 & 0,1 & 0,168 & $\begin{array}{l}\text { Berdistribusi } \\
\text { normal }\end{array}$ \\
\hline
\end{tabular}

Berdasarkan tabel 2 diatas diperoleh taraf signifikan 5\% didapat $\mathrm{L}_{\text {tabel }}=0,168$ minat belajar dengan diperoleh $\mathrm{L}_{\mathrm{o}}$ $<\mathrm{L}_{\text {tabel }}$ atau $(0,105<0,168)$ dan $\mathrm{L}_{0}<\mathrm{L}_{\text {tabel }}$ hasil belajar dengan diperoleh $(0,1<$ 0,168) maka $\mathrm{H}_{\mathrm{o}}$ diterima, sehingga sampel berasal dari populasi berdistribusi normal. 
Volume 2 Nomor 2, Edisi Desember 2019

Prodi PGSD Universitas Slamet Riyadi

ISSN 2620-6560 (print) ISSN 2620-746X (online)

\section{b. Uji Hipotesis}

\section{Minat Belajar}

Tabel 3. Hasil perhitungan Uji-t Minat

\begin{tabular}{llllllll}
\multicolumn{8}{c}{ Belajar siswa } \\
\hline Subjek & $\begin{array}{l}\text { Hasil } \\
\text { belajar }\end{array}$ & $\bar{x}$ & $\mathrm{~N}$ & $\mathrm{Md}$ & $\sum x^{2} d$ & thiung $^{\text {thing }}$ & tabel $^{\text {ata }}$ \\
\hline Kela II & Prete & 57, & 2 & 13, & 1004, & 11,6 & 2,06 \\
SDN & st & 8 & 7 & 8 & 1 & & \\
Mrangg & poste & 71, & & & & & \\
en & st & 7 & & & & & \\
Demak & & & & & & & \\
\hline
\end{tabular}

Berdasarkan analisis data minat belajar tabel 3 nilai pretest dan posttest dengan uji-t diperoleh nilai rata-rata pretest 57,9 dan rata-rata nilai posttest 71,7. Diperoleh $\mathrm{t}_{\text {hitung }}=11,6 \mathrm{db} \quad \mathrm{N}-1=27-1=$ 26 dengan taraf signifikan $5 \%$ sebesar 2,1 karena $t_{\text {hitung }}$ $>\mathrm{t}_{\text {tabel }}(11,6>2,1)$ maka hal ini menunjukan bahwa uji $\mathrm{t}$ angket minat belajar signifikan. Hal ini menunjukan bahwa ada pengaruh model pembelajaran Bahasa Indonesia materi memahami teks pendek dengan membaca lancar dan membaca puisi anak siswa kelas II SDN Menur Mranggen Demak.

\section{Hasil Belajar}

Tabel 4. Hasil Perhitungan Ujit Hasil Belajar Siswa

\begin{tabular}{llllllll}
\multicolumn{7}{c}{ t Hasil Belajar Siswa } \\
\hline Subjek & $\begin{array}{l}\text { Hasil } \\
\text { belajar }\end{array}$ & $\bar{x}$ & $\mathrm{~N}$ & $\mathrm{Md}$ & $\sum x^{2} d$ & $\mathrm{t}_{\text {hitung }}$ & $\mathrm{t}_{\text {thbel }}$ \\
\hline Kela II & Prete & ${ }^{62,}$ & 2 & 17, & 612,9 & 18,2 & 2,06 \\
SDN & st & 6 & 7 & 0 & & & \\
\cline { 2 - 3 } Mrangg & poste & 79, & & & & & \\
en & st & 6 & & & & & \\
Demak & & & & & & & \\
\hline
\end{tabular}

Berdasarkan analisis data hasil belajar tabel 4 nilai pretest dan posttest dengan uji-t diperoleh nilai rata-rata pretest 62,6 dan rata-rata nilai posttest 79,6. Diperoleh $t_{\text {hitung }}$ $=18,2 \mathrm{db} \quad \mathrm{N}-1=27-1=26$ dengan taraf signifikan $5 \%$ sebesar 2.05 karena $t_{\text {hitung }}>t_{\text {tabel }}(18,2>2,1)$ maka hal ini menunjukan bahwa uji t hasil belajar signifikan. Hal ini menunjukan bahwa ada pengaruh model pembelajaran Bahasa Indonesia materi memahami teks pendek dengan membaca lancar dan membaca puisi anak siswakelas II SDN Menur Mranggen Demak. 


\section{PEMBAHASAN}

\section{Minat Belajar Siswa}

Pada tahap pertama peneliti terlebih dahulu dilakukan uji normalitas awal dengan menggunakan pretest diperoleh $\mathrm{L}_{\mathrm{o}}$ $<\mathrm{L}_{\text {tabel }}$ atau $(0,06<0,2)$ maka $\mathrm{H}_{\mathrm{o}}$ diterima, sehingga sampel berasal dari populasi berdistribusi normal. Pada tahap akhir dilakukan kebali uji normalitas dengan menggunakan posttest. Berdasarkan perhitungan $\mathrm{L}_{\mathrm{o}}<\mathrm{L}_{\text {tabel }}$ atau $(0,105<0,168)$ dengan maka $\mathrm{H}_{\mathrm{o}}$ diterima, sehingga sampel berasal dari populasi berdistribusi normal.

Hasil penelitian dengan menggunakan model Numbered Head Together (NHT) berbantu media ular tanggamenunjukkan bahwa rata-rata pretest kelas II adalah 57,9 termasuk dalam kategori cukup baik. Sedangkan rata-rata posttest kelas II adalah $82 \%$ termasuk dalam kategori baik. Pada uji $t$ diperoleh $t_{\text {hitung }}=$ 11,551 > $t_{\text {tabel }}=2,056$ sehingga dapat diartikan terdapat perbedaan secara signifikan. Hal ini dapat menunjukkan secara jelas bahwa model Numbered Head Together (NHT) dinyatakan berpengaruh terhadap siswa minat belajar siswa kelas II pada mata pelajaran Bahasa Indonesia.

Menurut Slameto (2010: 180181) ada beberapa indikator minat belajar yaitu 1) Rasa suka (rasa senang); 2) Rasa antusias; 3) Perhatian; 4) Keinginan/kemauan; 5) Partisipasi aktif (rasa ingin tahu). Siswa yang mempunyai minat belajar tinggi ditandai dengan perasaan senang dalam pembelajaran, rasa antusias siswa dalam pembelajaran, keinginan atau kemauan siswa dalam pembelajaran serta partisipasi aktif siswa dalam pembelajaran. Dari aspek tersebut mendorong siswa untuk melakukan aktivitas belajar. Wujud kesadaran ini ditunjukan melalui keterlibatan siswa saat proses pembelajaran dikarenakan model Numbered Heads Together (NHT) berbantu media ular tangga Adit Sopo Jarwo yang digunakan membuat siswa menikmati pembelajaran dengan seksama dan saling berdiskusi antara siswa yang satu dengan yang lain, seperti saat 
siswa mencari pasangan dari kartu pintar yang diterima dan saat melakukan presentasi didepan kelas, siswa berebut untuk melakukan presentasi, sehingga tercipta suasana kelas menjadi sangat menyenangkan karena semua siswa terlibat aktif dalam pembelajaran yang dimana saat proses pembelajaran menggunakan model pembelajaran Numbered Heads Together (NHT) berbantu media ular tangga Adit Sopo Jarwo terbukti berpengaruh positif dalam meningkatkan minat belajar siswa.

Oleh karena itu, siswa yang mempunyai minat belajar yang tinggi pasti akan berusaha keras untuk mendapatkan hasil belajar yang terbaik.

\section{Hasil Belajar}

Sedangkan pada hasil belajar siswa, uji normalitas awal dengan menggunakan pretest diperoleh $\mathrm{L}_{\mathrm{o}}<\mathrm{L}_{\text {tabel }} \quad$ atau $\quad(0,101<0,168)$ dengan $\alpha=5 \%$ dan $\mathrm{N}=27$ maka $\mathrm{H}_{\mathrm{o}}$ diterima, sehingga sampel berasal dari populasi berdistribusi normal. Pada tahap akhir dilakukan kembali uji normalitas dengan menggunakan posttest.
Berdasarkan perhitungan diperoleh $\mathrm{L}_{\mathrm{o}}<\mathrm{L}_{\text {tabel }} \quad$ atau $\quad(0,100<0,168)$ dengan $\alpha=5 \%$ dan $\mathrm{N}=27$ maka $\mathrm{H}_{\mathrm{o}}$ diterima, sehingga sampel berasal dari populasi berdistribusi normal.

Hasil penelitian dengan menggunakan model Numbered Heads Together (NHT) berbantu media ular tangga Adit Sopo Jarwo menunjukkan bahwa rata-rata nilai pretest kelasII adalah 62,6. Sedangkan rata-rata nilai posttest kelas II adalah 79,6 dengan persentase kenaikan sebesar 17,03\%. Hal ini dapat menunjukkan secara jelas bahwa model Numbered Heads Together (NHT) berbantu media ular tangga Adit Sopo Jarwo dinyatakan berpengaruh terhadap hasil belajarsiswa kelas II pada mata pelajaran Bahasa Indonesia. Hal tersebut diperkuat dengan hasil perhitungan uji $t$ minat belajar diperoleh $t_{\text {hitung }}=18,2>t_{\text {tabel }}=2,1$.

Penerapan model pembelajaran Numbered Heads Together (NHT) berbantu media ular tangga Adit Sopo Jarwo telah terbukti meningkatkan hasil belajar 
siswa. Menurut Gagne, hasil belajar adalah terbentuknya konsep, yaitu kategori yang kita berikan pada stimulus yang ada di lingkungan yang menyediakan skema yang terorganisasi untuk mengasimilasi stimulus-stimulus baru dan menentukan hubungan di dalam dan diantara kategorikategori (Purwanto 2013: 42). Sedangkan menurut Slameto (2013: 2) hasil belajar adalah perubahan tingkah laku dalam proses belajar terjadi akibat interaksi yang dilakukan siswa dengan lingkungannya. Jadi hasil belajar merupakan pencapaian tujuan belajar dan hasil belajar sebagai produksi proses belajar.

Walsiman dalam Susanto (2013:12) hasil belajar yang dicapai oleh peserta didik merupakan hasil interaksi antara berbagai faktor yang mempengaruhinya, baik faktor internal maupun faktor eksternal. Faktor internal merupakan faktor yang bersumber dari dalam diri siswa seperti minat belajar siswa yang mempengaruhi belajarnya. Faktor eksternal merupakan faktor yang berasal dari luar diri siswa yang mempengaruhi hasil belajar siswa.Seorang siswa harus memiliki minat belajar yang baik karena minat belajar merupakan suatu usaha atau jalan yang harus dilalui oleh siswa untuk mendapatkan tujuan belajar atau hasil belajar yang maksimal. Minat belajar sangatlah penting dan tidak boleh diabaikan oleh guru di sekolah. Karena dengan adanya minat untuk belajar, guru akan lebih mudah dalam mencapai tujuan pembelajaran dan hasil belajar yang memuaskan. Minat belajar merupakan salah satu faktor yang mempengaruhi belajar siswa. Sesuai dengan Slameto (2010:180), pada dasarnya minat terhadap sesuatu merupakan hasil belajar dan menyokong belajar selanjutnya. Pernyataan tersebut menguatkan hasil penelitian yang telah diperoleh. Semakin tinggi minat belajar siswa terhadap mata pelajaran Bahasa Indonesia, maka hasil belajar Bahasa Indonesia juga tinggi. Sebaliknya semakin rendah minat belajar terhadap mata pelajaran Bahasa Indonesia, maka 
hasil belajar Bahasa Indonesia juga akan rendah. Kesempatan belajar semakin banyak dan optimal jika siswa tersebut menunjukkan ketekunannya dalam mempelajari Bahasa Indoneisa sehingga dapat membangkitkan minat untuk belajar. Siswa yang telah termotivasi dalam belajar,ia akan lebih bersemangat dalam mempelajarinya sehingga timbul minat belajarnya. Siswa yang mempunyai minat belajar yang tinggi akan selalu berusaha mencari, menggali, dan mengembangkan potensi dasar, sehingga menimbulkan percaya diri untuk mendapatkan hasil belajar yang diharapkan. Dengan demikian dapat disimpulkan bahwa pembelajaran dengan menggunakan model Numbered Heads Together (NHT) berbantu media ular tangga Adit Sopo Jarwo lebih baik dibandingkan dengan pembelajaran yang tidak di beri perlakuan. Karena nilai rata-rata kelas II SD N Menur Mranggen Demak sesudah diberi perlakuan dengan model pembelajaran Numbered Heads Together (NHT) berbantu media ular tangga Adit Sopo Jarwo lebih tinggi dibandingkan nilai rata-rata sebelum diberikan perlakuan. Dengan demikian model pembelajaran Numbered Heads Together (NHT) berbantu media ular tangga Adit Sopo Jarwo memiliki pengaruh terhadap minat dan hasil belajar Bahasa Indoneisa materi memahami teks pendek dengan membaca lancar dan membaca puisi anak siswa kelas II SD N Menur Mranggen Demak

$\begin{array}{ccc}\text { SIMPULAN } & & \\ \text { Ada } & \text { pengaruh } & \text { model } \\ \text { pembelajaran } & \text { Numbered } & \text { Heads }\end{array}$
Together (NHT) berbantu media ular tangga Adit Sopo Jarwo terhadap minat belajar Bahasa Indonesia materi memahami teks pendek dengan membaca lancar dan membaca puisi anak siswa kelas II SD $\mathrm{N}$ Menur Mranggen Demak. Dengan uji $t$ diperoleh $t_{\text {hitung }}=11,6$ dan untuk $\alpha=$ $5 \%$ dengan $\mathrm{db}=27$ dilihat dari tabel distribusi $\mathrm{t}$ diperoleh $\mathrm{t}_{\text {tabel }}=2,06$. Perhitungan menunjukkan bahwa $t_{\text {hitung }}>t_{\text {tabel }}$ atau 11,6 $>2,06$ maka hal ini menunjukkan bahwa uji $\mathrm{t}$ minat 
belajar signifikan sehingga $\mathrm{H}_{0}$ ditolak. Berdasarkan perhitungan tersebut maka dapat disimpulkan uji hipotesis statistik $\mathrm{H}_{\mathrm{a}}$ diterima, artinya ada perbedaan rata-rata nilai pretest dan posttest. Dan ada pengaruh model pembelajaran Numbered Heads Together (NHT) berbantu media ular tangga Adit Sopo Jarwo terhadap minat belajar Bahasa Indonesia materi memahami teks pendek dengan membaca lancar dan membaca puisi anak siswa kelas II SD $\mathrm{N}$ Menur Mranggen Demak. Dengan uji $t$ diperoleh $\mathrm{t}_{\text {hitung }}=18,2$ dan untuk $\alpha=$ $5 \%$ dengan $\mathrm{db}=27$ dilihat dari tabel distribusi $\mathrm{t}$ diperoleh $\mathrm{t}_{\text {tabel }}=2,06$. Perhitungan menunjukkan bahwa $\mathrm{t}_{\text {hitung }}>\mathrm{t}_{\text {tabel }}$ atau 18,2 $>2,06$ maka hal ini menunjukkan bahwa uji $\mathrm{t}$ hasil belajar signifikan sehingga $\mathrm{H}_{0}$ ditolak. Berdasarkan perhitungan tersebut maka dapat disimpulkan uji hipotesis statistik $\mathrm{H}_{\mathrm{a}}$ diterima, artinya ada perbedaan rata-rata nilai pretest dan posttest.

Oleh karena itu, dapat disimpulkan bahwa model Numbered Heads Together (NHT) berbantu media ular tangga Adit Sopo Jarwo berpengaruhterhadap minat belajar Bahasa Indonesia materi memahami teks pendek dengan membaca lancar dan membaca puisi anak siswa kelas II SD N Menur Mranggen Demak.

\section{DAFTAR PUSTAKA}

Djamarah,Syaiful Bahri. 2010. Guru dan Anak Didik dalam Interaksi Edukatif Suatu Pendekatan Teoritis Psikologis. Jakarta: Rineka Cipta

Purwanto. 2013. Evaluasi Hasil Belajar. Yogyakarta: Pustaka Pelajar

Slameto. 2010. Belajar dan FaktorFaktor yang Mempengaruhinya. Jakarta: Rineka Cipta. 2013. Belajar dan FaktorFaktor yang Mempengaruhinya. Jakarta: Rineka Cipta.

Sugiyono. 2016. Metode Penelitian Kuantitatif, Kualitatif, dan $R \& D$. Bandung: Alfabeta.

Susanto.2013. Teori Belajar dan Pembelajaran di Sekolah Dasar. Jakarta: Kencana Prenada Media Group.

Sutikno, Sobry. 2013. Belajar dan Pembelajaran. Lombok: Holistica. 